\title{
The Effect of Macroeconomic Indicators and the Addition of Tax Payers Against Tax Receipts in Indonesia
}

\author{
I.G.S. Putra \& M. Kustiawan \\ Universitas Pendidikan Indonesia \\ Bandung, Indonesia \\ D. Sari \\ Universitas Widyatama \\ Bandung, Indonesia
}

\begin{abstract}
The national economy during a period of ups and downs as a result of changes in the economic environment that is changing dynamically. Rise and fall of economic growth in the aggregate at least describe how much output can be achieved within a certain period of development. The role of taxes as well as can be seen by its contribution to fund government spending. As a component of the largest state income Tax Receipts is the main source to finance state spending, the researchers interested in studying with the title "The Effect of Macroeconomic Indicators and The addition of Taxpayers Against Tax Receipts in Indonesia" The method used in this research is multiple linear regression using descriptive and verificative methods, population in this research is data of economic growth (GDP), exchange, SBI, inflation, oil prices, tax payers of the tax receipts in Indonesia the period 2005-2014. While the sample used is as much as the study population using census method. This study was processed with SPSS so it can result in that GDP economic growth, exchange, SBI, inflation, oil prices and tax payers significant influence simultaneously and partially on tax receipts Indonesia year 2005-2014.
\end{abstract}

Keywords—macroeconomic; tax payer; tax receipt

\section{INTRODUCTION}

The higher a country's economic growth rate relative reflects how much the level of welfare of life for the community. The national economy for several periods has experienced ups and downs as a result of changing dynamically changing economic environment. The ups and downs of aggregate economic growth at least illustrate how much output can be achieved in the construction of a particular period. In this case, a high rate of economic growth reflects the increase in output generated in domestic economic activity. Meanwhile, the decline in the level of economic activity reflects the decline in national economic activity at a certain period [1]. In more detail the development of macroeconomic assumptions of Indonesia in 2011-2014 can be seen in Table 1 below:

TABLE 1. DEVELOPMENT OF MACROECONOMIC INDICATORS 2011-2014.

\begin{tabular}{|l|l|l|l|l|}
\hline Indicator & $\mathbf{2 0 1 1}$ & $\mathbf{2 0 1 2}$ & $\mathbf{2 0 1 3}$ & $\mathbf{2 0 1 4}$ \\
\hline & Realization & Realization & Realization & Realization \\
\hline (PDB) Economic Growth (\%) & 6.2 & 6.0 & 5.6 & 5.0 \\
\hline Inflation y.o.y (\%) & 5.4 & 4.3 & 8.4 & 8.4 \\
\hline $\begin{array}{l}\text { Rupiah exchange rate } \\
\text { IDR/US\$) }\end{array}$ & 8773 & 9419 & 11,563 & 11,800 \\
\hline 3 months SBI on average (\%) & 6.0 & 5.75 & 7.50 & 7.75 \\
\hline Oil Price (USS/barel) & 111.5 & 112.7 & 105.9 & 105.0 \\
\hline $\begin{array}{l}\text { Lifting Oil } \\
\text { (million barrels per day) }\end{array}$ & 900 & 861 & 825 & 818 \\
\hline
\end{tabular}

Source: Ministry of Finance 2015.

Based on the above phenomenon, the authors intend to conduct research in this research with the title "The Influence of Macroeconomic Indicators and Addition of Taxpayers To Tax Receipts in Indonesia". By considering the background and description that has been disclosed then the problems to be analyzed in this research are:

1. What is the effect of macroeconomic indicators on Tax Receipts in Indonesia?

2. How does the taxpayer increase in Tax Receipts in Indonesia?

3. How do macroeconomic indicators influence and the number of taxpayers increase simultaneously to Tax Receipts in Indonesia? 
in public purchasing power, as the income level also decreases. Inflation in principle is an economic phenomenon in the form of rising price levels [6]. An increase in the price of one or two items alone can not be called inflation, unless the increase is widespread or causes an increase in the bulk of the price of other goods. The formula:

$\operatorname{Inf}=\frac{\text { WKt }-\mathrm{mKt}_{\mathrm{I}} \mathrm{a}}{\text { IHKt}-1} \times 100$ Growth:

$$
\begin{gathered}
\text { Economic Growth }=(\text { PDRBt }-\mathrm{PDRBt}-1) /(\mathrm{PDRBt}-1) \times \\
100 \%
\end{gathered}
$$

\section{B. Taxpayer}

Law Number 28 in 2007 concerning General Provisions and Tax Procedures Article 1 paragraph 2 mentioned the definition of Taxpayer is an individual or entity, including taxpayers, tax-cutters and tax collectors who have rights and tax obligations in accordance with the provisions tax laws. The formula:

\section{Value of exchange $=\frac{\text { (Exchange Rate }+ \text { Purchase Rate) }}{2}$}

\section{Macroeconomics}

Macroeconomics focuses on the behavior and economic policies that can affect the level of consumption and investment; the trade balance and payment of a country; important factors affecting changes in prices and wages; fiscal and monetary policies; the amount of money in circulation; interest rates; and the amount of state debt. Macroeconomics is a branch of economics that studies economic phenomena in aggregate or overall, for example, economic growth, unemployment rate, inflation, interest rates, currency exchange rates, money supply in an economy. Macroeconomic explanations include economic changes that affect all households, companies, and markets simultaneously [4]. The macroeconomic variables in this study as follows:

1). Economic growth (GDP)

The economic growth of a country is seen from the growth of Gross Domestic Product or commonly abbreviated as GDP (Gross Domestic Product usually abbreviated GDP) of the country. Economists measure the total quantity of goods and services produced in an economy unaffected by a change in the prices of those goods and services. This measure is called real GDP (real GDP) i.e. production of goods and services that are valued at constant prices [4].

\section{2). Inflation}

Inflation is a tendency for continuous increases in general prices. Inflation can be defined "As a process of rising prices prevailing in an economy" [5]. Inflation will lead to a decrease

\section{3). SBI Interest Rate}

Bank Indonesia Certificates (SBI) are securities issued by Bank Indonesia in recognition of debt and are traded under a discount system [7]. While the SBI Interest Rate is the value to be paid by Bank Indonesia to investors on short-term securities issued by Bank Indonesia. In this regard, Bank Indonesia uses the BI rate mechanism (Bank Indonesia interest rate), ie Bank Indonesia announces the target of SBI interest rate desired by Bank Indonesia for auction at a certain period of time.

\section{4). Exchange Rate}

The exchange rate i.e. the exchange rate is the price of one currency expressed in terms of another currency [8]. Exchange rate is the exchange between two different currencies, it will get a comparison of the value/price between the two currencies [9].The middle rate calculation method commonly used by Bank Indonesia is to add up the selling rate and buying rate then divided by two. So it appears the middle exchange rate as follows.

\section{5). Crude Oil Prices Indonesia}

According to the Regulation of the Minister of Home Affairs and Mineral Resources of the Republic of Indonesia No. 23 of 2015, Indonesia crude oil price formula is the formula used to calculate and determine the price of crude oil in Indonesia. The Price Team is a team assigned to conduct an evaluation and submit a proposal to stipulate a formula for the price of Indonesian crude oil to be proposed to the minister.

\section{METHOD}

\section{A. Method}

The research method used in this research is descriptive and verificative method. Descriptive method is done to know and be able to explain characteristics of variables studied in a situation [10]. Meanwhile verifical method is a method of research that explains a certain relationship, or determines difference group or freedom (independence) two or more factors in the situation [11]. 


\begin{tabular}{|l|l|l|l|l|}
\hline \multirow{2}{*}{ Variable } & Kolmogorov-smirnov Z & \multicolumn{2}{|l|}{$\begin{array}{l}\text { Collinearity } \\
\text { Statistics }\end{array}$} & Durbin- \\
\cline { 3 - 5 } & & Tolerance & VIF & \\
\hline Oatson \\
\hline Addition Of Taxpayers & 0.579 & 0.111 & 9.044 & \\
\hline Tax Receipts & 0.402 & 0.141 & 4.117 & \\
\hline
\end{tabular}

\section{Data Collection Techniques}

The data collection techniques undertaken in this study were to collect from each period of time to time taken from Data processed either from the Central Bureau of Statistics (BPS), Bank Indonesia (BI) or the annual report of the finance ministry and the annual report of the DJP later used as research sample. The paradigm model is made as shown below.

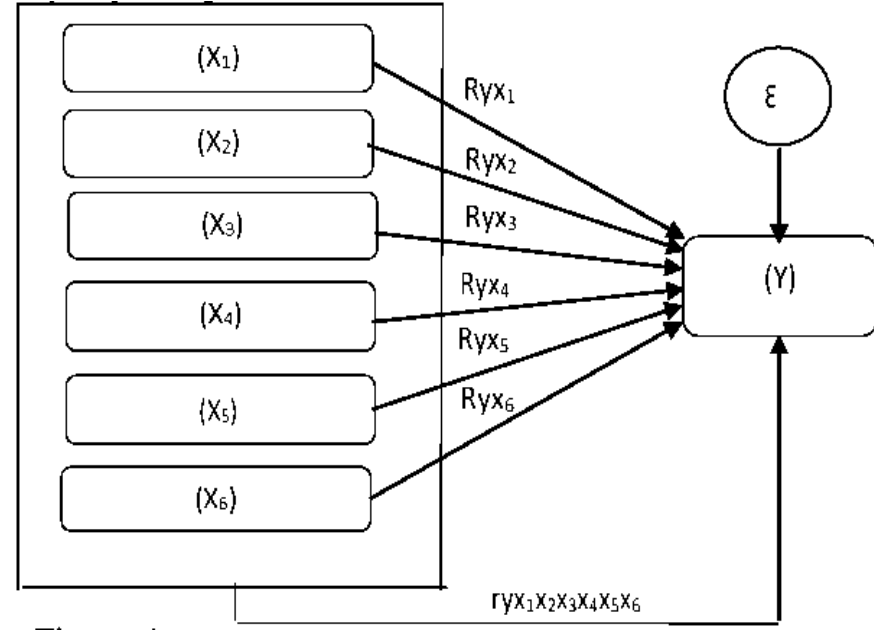

Fig. 1. Model of the research paradigm

\section{RESULTS AND DISCUSSION}

In searching for the validity of multiple regression analysis, this research used the classical assumption test, which aims to find out whether the regression model obtained can produce a good estimator. As for the four classical assumptions test are:

\section{A. Normality Test}

TABLE 2. NORMALITY TEST.

\begin{tabular}{|c|c|c|c|c|}
\hline \multirow{2}{*}{ Variable } & \multirow{2}{*}{ Kolmogorov-smirnov Z } & \multicolumn{2}{|c|}{$\begin{array}{l}\text { Collinearity } \\
\text { Statistics }\end{array}$} & \multirow{2}{*}{\begin{tabular}{|l} 
Durbin \\
Watson
\end{tabular}} \\
\hline & & Tolerance & $V I F$ & \\
\hline \multicolumn{5}{|l|}{ Constant } \\
\hline PDB & 0.393 & 0.138 & 7.238 & \multirow{2}{*}{1.250} \\
\hline Inflation & 0,526 & 0.370 & 2.702 & \\
\hline Rupiah & 1,576 & 0.139 & 7.202 & \\
\hline SBI & 0.485 & 0.123 & 8.151 & \\
\hline
\end{tabular}

Based on Table 2 above, it shows that the value of kolmogorov smirnov for GDP $(0.393>0.05)$, inflation $(0.526$ $>0.05)$, exchange rate $(1.576>0.05)$, $\mathrm{SBI}(0.485>0.05)$, oil price $(0.897>0.05)$ number of taxpayers $(0.579>0.05)$, and tax receipts $(0.402>0.05)$, it can be concluded that the population data is normally distributed or fulfilled the assumption of normality.

\section{B Multicolinearity Test}

Based on the above table the tolerance values for each variable: $\operatorname{GDP}(0.138>0.01)$, inflation $(0.370>0.01)$, SBI $(0.123>0.01)$, oil price $(0.724>0.01)$, and number of taxpayers $(0.141>0.01)$. So it can be concluded not occurs multicollinearity between independent variables, and based on the above table obtained VIF for each variable: GDP (7.328 < $10)$, inflation $(2.702<10)$, exchange rate $(7.202<10)$, SBI $(8.151<10)$, oil price $(9.044<10)$, taxpayer number $(4.117<$ 10). So it can be concluded not multikolinieritas between independent variables, meaning that among the independent variables there is not a strong enough correlation between free variables and decent data used for multiple regression analysis.

\section{Autocorrelation Test}

One way to detect symptoms of autocorrelation is by using the Durbin-Watson method with a range of $-2<\mathrm{DW}<2$, then there is no autocorrelation. Based on the results obtained statistical value Durbin-Watson $(\mathrm{DW})=1.250$ then $-2<1.250$ $<2$ can be concluded that there is no autocorrelation [12].

\section{Heteroscedasticity Test}

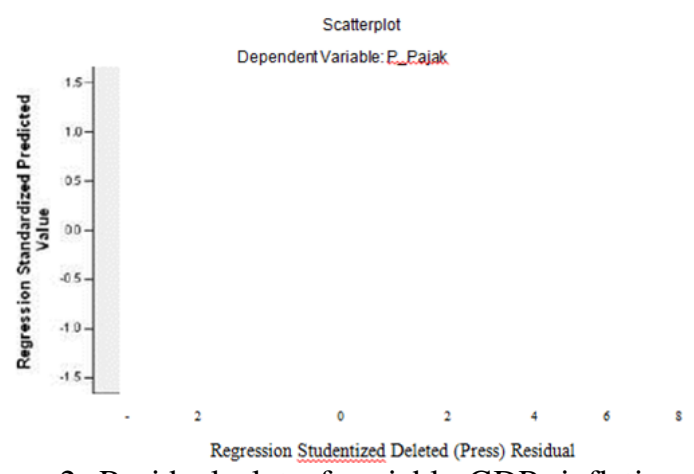

Figure 2. Residual plot of variable GDP, inflation, exchange rate, SBI, oil price, number of taxpayer to tax receipts. 
In Figure2, the scatterplot graph shows that residual plots spread evenly above and below the number 0 and residual plots do not form a particular pattern. Then it can be concluded that there is no problem of heteroskedasticity, meaning the annoying variable $£$ (error) has the same variant along the observation of various values of independent variables, this means that the data on each independent variable has the same range, so the regression model is feasible to be used in doing testing.

\section{1) Multiple Regression Analysis}

Based on the calculation in the table 3, obtained the form of multiple linear regression equation as follows:

$$
\begin{aligned}
\mathrm{Y}= & 2.358+0.062 \mathrm{X} 1+0.004 \mathrm{X} 2+0.443 \mathrm{X} 3+0.010 \mathrm{X} 4- \\
& 0.039 \mathrm{X} 5+0.489 \mathrm{X} 6+\mathrm{Y}
\end{aligned}
$$

\begin{tabular}{|c|c|c|c|c|}
\hline \multirow{2}{*}{ Variable } & \multicolumn{2}{|c|}{ Unstandardized Coef } & \multirow{2}{*}{- t_test $S$} & \multirow{2}{*}{ iig. } \\
\hline & $B$ & Std. Error & & \\
\hline $\mathrm{X} 1 \longrightarrow \mathrm{Y}$ & 0.062 & 0.034 & 2.844 & $0.026^{*}$ \\
\hline $\mathrm{X} 2-\mathrm{Y}$ & 0.443 & 0.254 & 2.743 & $0.010^{\text {*** }}$ \\
\hline $\mathrm{X} 3-\mathrm{Y}$ & 0.010 & 0.014 & 2.556 & $0.018^{\text {*** }}$ \\
\hline $\mathrm{X} 4 \longrightarrow \mathrm{Y}$ & 0,004 & 0,003 & 3.218 & $0.050^{*}$ \\
\hline $\mathrm{X} 5-\mathrm{Y}$ & -0.039 & 0.099 & 2.388 & $0.024 *$ \\
\hline $\mathrm{X} 6 \longrightarrow \mathrm{Y}$ & 0.489 & 0.127 & 3.852 & $0.031 *$ \\
\hline
\end{tabular}

TABLE 3. COEFFICIENTS

Notes: $* \mathrm{p}<.05 ; * * \mathrm{p}<.01 ; * * * \mathrm{p}<.001$

\section{2) Influence Of GDP (X1) On Tax Receipts (Y)}

The results obtained from the comparison t_test with $\mathrm{t}$ _table is H0 rejected because - $\mathrm{t}$ _table $(-1.85)<\mathrm{t}$-test $(2.743)$ or t_test (2.743) > t_tabel (1.85) then the hypothesis can be concluded there is a significant influence between GDP (X1) on Tax Receipts (Y) Indonesia Year 2005-2014. Based on the hypothesis testing that the variable of the exchange rate (X1) has an effect on Tax Receipts (Y), this is in line with the research of Rahmanta (2009) [13] and Sinaga (2010) [14] GDP has a positive effect on Tax Receipts in Indonesia. Economic growth as reflected in the increase in GDP will affect the state revenue, especially the increase in Tax Receipts. Economic growth, which is the percentage increase of GDP in the real value of a certain year compared to the previous year, has a positive effect on Tax Receipts, especially through the increase of public income and consumption level. Increasing public incomes will increase the amount of Income Tax paid by residents who have paid taxes, and may shift the position of certain residents from non-taxpayer groups to taxpayers, or from taxpayers at certain tariffs to higher tariffs in the case of progressive tariffs. While the increase in consumption due to economic growth will increase VAT revenue because the tax base to calculate VAT is the selling or replacement value of economic transactions. As consumption increases, as the VAT rate is a single tariff, then VAT revenue will also increase. So it can be concluded that GDP has a significant effect on Tax Receipts.

\section{3) Effect Of The Exchange Rate (X2) On Tax Receipts (Y)}

The results obtained from the comparison t_test with $\mathrm{t}$ ttable is H0 rejected because - $\mathrm{t}$ _table $(-1.85)<\mathrm{t}$-test $(2.743)$ or t_test (2.743) > t_table (1.85) then the hypothesis can be concluded there is a significant influence between the exchange rate (X2) on Tax Receipts (Y) Indonesia Year 20052014. The Rupiah exchange rate against the US Dollar has a positive influence on Tax Receipts. This is in line with Sinaga's research (2010) and Andika (2015). For Income Tax, the Rupiah exchange rate increase will pay tax on income received by foreigners, and income tax from petroleum and gas (PPh Migas). While Value Added Tax (VAT) will increase in line with the increase of Rupiah exchange rate against US Dollar, especially from import VAT and import PPnBM. Thus it can be concluded that the exchange rate of Rupiah to US Dollar has a significant effect on Tax Receipts.

\section{4) Effect Of SBI (X3) On Tax Receipts (Y)}

The results obtained from the comparison t_test with $\mathrm{t}$ _table is $\mathrm{H} 0$ rejected because $-\mathrm{t}$-table $(-1.85)<\mathrm{t}$-test $(2.844)$ or t_test (2.556) > t_tabel (1.85) then the hypothesis can be concluded there is a significant influence between SBI (X3) on Tax Receipts (Y) Indonesia Year 2005-2014. Basically, the interest rate of Bank Indonesia Certificates is closely related to the inflation rate. The results of this study are in line with a research which states that inflation has a significant effect on Tax Receipts [15]. This happens because the interest rate of Bank Indonesia Certificates is one way for the government through Bank Indonesia to cope with inflation. Therefore, by playing these two variables, Bank Indonesia can control the monetary stabilization in the country of Indonesia, and also if monetary stability can be created then the national income will be stable and can even creep up, thus income Tax Receipts will also increase as Indonesia's economy stabilizes. Changes in the interest rate of Bank Indonesia Certificates will have a positive effect on Tax Receipts in Indonesia.

\section{5) Inflation influence (X4) on tax receipts $(Y)$}

The results obtained from the comparison t_test with t_table is H0 rejected because -t_table $(-1.85)<\mathrm{t}$ _test $(3.218)$ or t_test (3.218) > t_table (1.85) then the hypothesis can be concluded there is a significant influence between Inflation (X4) on Tax Receipts (Y) Indonesia Year 2005-2014. The 
inflation variable has a significant influence on Tax Receipts. This is in line with Andika's research (2015) [15]. The trend is caused by inflation can change the pattern of allocation of factors of production. This change can occur through a decrease in demand for various goods affected by inflation which can lead to change in the production of certain goods. The influence of rising inflation coupled with the length of distribution channels will cause the price of goods and services to increase, it will affect the purchasing power and transactions of goods and services that will reduce the Tax Receipts while if inflation is in a stable state it can encourage economic growth, because it can encourage entrepreneurs, to further expand production. Entrepreneurs are excited about expanding production, because with the rising prices they get more profits. In addition, the expansion of production has other positive effects in the form of providing new jobs. So it can be concluded that inflation has a significant effect on Tax Receipts.

\section{6) Effect Of Oil Price (X5) On Tax Receipts (Y)}

The results obtained from the comparison of t_test with $\mathrm{t}$ _table is H0 rejected because - $\mathrm{t}$ _table $(-1.85)<\mathrm{t}$-test $(2.388)$ or t_test (2.388) > t_table (1.85) then the hypothesis can be concluded there is significant influence between oil price (X5) Tax (Y) Indonesia Year 2005-2014. Based on the results of analysis that the variable oil prices negatively affect the Tax Receipts. Increased oil prices resulted in higher production costs. In terms of demand, changes in oil prices will have an impact on consumption and investment. Because of these effects, the total cost of production is high, thus potentially depressing the performance of the import-based business. As a result, the increase in international oil prices leads to a decrease in the production of goods and services, followed by low purchasing power, resulting in lower VAT revenue and an impact on declining Tax Receipts. Investment may also be affected, if oil prices fall, will encourage producers to replace their machines use less fuel into the use of more intensive machines in consuming energy, so that income will increase and in line with increased Tax Receipts.

\section{7) Effect Of Taxpayers (X6) On Tax Receipts (Y)}

The results obtained from the comparison t_test with $\mathrm{t}$ _table is H0 rejected because - $\mathrm{t}$ _table $(-1.85)<\mathrm{t}$ _test $(3.852)$ or t_test (3.852) > t_table (1.85) then the hypothesis can be concluded there is a significant influence between the number of taxpayers (X6) against Tax Receipts (Y) Indonesia Year 2005-2014. Based on the analysis that the number of taxpayers has a significant positive effect on Tax Receipts. This is in line with the research results Rima (2013), states that increasing the number of taxpayers strongly support income Tax Receipts in KPP Pratama Manado. The relationship amount of tax is declared very strong, this relationship shows the greater the number of taxpayers, the greater the amount of Tax Receipts.

\section{CONCLUSION AND SUGGESTION}

Based on the results of the test analysis and the discussion that have been described in the previous chapter it can be concluded as follows:

1. Influence of macroeconomic indicators to Tax Receipts in Indonesia, namely:

a. There is a significant positive influence between GDP (X1) on Tax Receipts (Y) Indonesia Year 2005-2014 and variable GDP able to explain variable of Tax Receipts that is equal to $24.6 \%$.

b. There is a significant positive influence between the exchange rate (X2) on Tax Receipts (Y) Indonesia Year 2005-2014 as well as the exchange rate variable able to explain variable Tax Receipts that is equal to $20.3 \%$.

c. There is a significant positive influence between SBI (X3) on Tax Receipts (Y) Indonesia Year 2005-2014 and SBI variable able to explain variable of Tax Receipts that is equal to $64.3 \%$.

d. There is a significant positive influence between the Inflation (X4) on Tax Receipts (Y) Indonesia Year 2005-2014 and Inflation variable able to explain the variable Tax Receipts that is equal to $8 \%$.

e. There is a significant negative effect between oil price (X5) on Tax Receipts (Y) Indonesia Year 2005-2014 and variable of oil price able to explain variable of Tax Receipt which is equal to $71 \%$.

2. Based on the results obtained that there is a significant positive influence between the number of taxpayers (X6) on Tax Receipts (Y) Indonesia Year 2005-2014 and variable amount of taxpayers able to explain the variable Tax Receipts that is equal to $93 \%$.

3. Based on the results obtained there is influence simultaneously Economic Growth GDP (X1), Exchange Rate (X2), SBI (X3), Inflation (X4), Oil Price (X5) and Taxpayer Number (X6) on Tax Receipts (Y) Indonesia Year 2005-2014 and simultaneously variable of GDP (X1), Exchange rate (X2), SBI (X3), Inflation (X4), Oil Price (X5), Taxpayer Number (X6) able to explain variable of Tax Receipts that is equal to $98.5 \%$.

Based on analysis and discussion, the suggestions that can be used as input materials are as follows:

1. Based on the above conclusion is known that the total Tax Receipts response to GDP growth is still low that should be able to achieve $8-9 \%$ per year. Therefore, it is suggested that this figure can be increased so that the future of Tax Receipts response to economic growth can be even greater. 
This is important because the greater the Tax Receipts response to GDP growth, the increase in Tax Receipts will be greater at a certain level of economic growth. Efforts to improve the response can, among others, be done by improving the quality of tbsp of the taxation apparatus and improving tax administration.

2. For the government should be more concerned about the macroeconomy. As a foundation is the inflation that greatly affects the viability of a country, if the inflation rate can be controlled properly, then income from tax sector will be optimized. Unlike for the interest rate of certificates of Bank Indonesia (SBI), SBI aims to tackle inflation, so the government should also pay attention to SBI so that inflation does not exceed the normal threshold. Exchange rate is also very important for the perpetrators of the economy that conducts international trade, and also the exchange rate resulting in a difference in profit or loss on the perpetrators who conduct export and import activities.

3. For further researchers, especially regarding macroeconomics and Tax Receipts, better macroeconomic indicators are added more closely related to the amount of income Tax Receipts. It can be added about the unemployment rate as well as the level of employment.

\section{REFERENCES}

[1] Simanjuntak, H.C. \& Muklis, I. 2012, Economic dimension of the taxation in economic development. Bogor: Success Issuance Publishers.

[2] Dumairy, D. 1997. Indonesia's economy. Jakarta: Erlangga Publishers.

[3] Hutagaol, J. 2007. Taxation of contemporary issues. Jakarta: Graha Ilmu.

[4] Mankiw, N.G. 2004. Principles of economics, introduction to macro economics (3rd Edition). Harvard University: Publisher Salemba Empat.

[5] Sukirno, S. 2010. Macroeconomics: Introduction theory (Third edition). Jakarta: PT. Raja Grasindo Perseda.

[6] Lipsey, R. 1992. Introduction macroeconomics. Jakarta: Binarupa Aksara.

[7] Siamat, D. 2001. Management of financial institutions (Third edition). Jakarta: Agency Publisher Faculty of Economics University of Indonesia.

[8] Rodriguez, R.M. \& Carter, E. 2006. International financial management. New York: McGraw Hill.

[9] Hermuningsih, S. 2012. Effect of profitability, size on corporate value with capital structure as intervening variable. Business Journal Practice 16(2): 232-24

[10] Sekaran, Uma. 2011. Research methods for business edition I and 2. Jakarta: Salemba Empat.

[11] Sekaran, U. 2006. Research methodology for business. Jakarta: Salemba Empat.

[12] Gujarati, D. \& Porter, D. 2003. Multicollinearity: What happens if the regressors are correlated. Basic Econometrics 363.

[13] Rahmanta, R. 2009. Pengaruh produk domestik bruto dan SBI terhadap penerimaan pajak di Indonesia. QE Journal 1 (1).

[14] Sinaga, A.R. 2010. Influence of variables-macro economy variables on tax receipts in Indonesia. Jakarta: Faculty of Economics, Master of Planning and Public Policy.

[15] Andika, F.K. \& Jauhar, A. 2015. Influence of inflation rate, interest rate of Bank Indonesia certificate, and rate of exchange against income of income tax (Study on income tax receipts in the period of 2005-2014) Taxation, Department of Business Administration, Faculty of Science
Administration - Taxation (JAB) 5(2). 